\title{
OBOWIAZZEK ZGŁOSZENIA UMOWY O DZIEŁO DO ZUS - USPRAWNIENIE SYSTEMU KONTROLI W ŚWIETLE KONSTYTUCYJNYCH ZASAD RÓWNOŚCI, PROPORCJONALNOŚCI I AUTONOMII INFORMACYJNEJ
}

\begin{abstract}
Obligation to notify Social Security Agency about a specific work contract - improvement of the control system in the light of constitutional principles of equality, proportionality and information autonomy

The purpose of the paper is to analyze obligation to notify Social Security Agency about concluded specific work contracts, which was introduced as of 1 January 2021 in the social security system act. Firstly, the way in which the new obligation was introduced raises significant doubts. Under the guise of anti-crisis measures, a new obligation has been introduced in the Anti-Crisis Shield, which has little to do with its purpose. Secondly, the prima facie technical obligation also raises practical doubts, but more importantly, it prompts questions about its compliance with the constitutional principles of equality, proportionality and information autonomy. Fulfillment of the obligation results in transfer to the Social Security Agency of significant data on legal relationship that are - as a rule - indifferent from the perspective of the social security system, the scope of which is not determined by a statute, but by a sub-statutory act.
\end{abstract}

Słowa kluczowe: umowa o dzieło, ubezpieczenia społeczne, Konstytucja

Keywords: contract of specific work, social security, Constitution

ASJC: 3308, JEL: K31

\section{Uwagi wstępne}

Umowa o dzieło co do zasady nie stanowi tytułu do ubezpieczeń społecznych i ubezpieczenia zdrowotnego. Od 1 stycznia 2021 roku znalazła się jednak w centrum zainteresowania Zakładu Ubezpieczeń Społecznych (dalej: „ZUS”) za sprawą art. 22 ustawy z dnia 31 marca 2020 roku o zmianie ustawy o szczególnych rozwiązaniach związanych z zapobieganiem, 
przeciwdziałaniem i zwalczaniem COVID-19, innych chorób zakaźnych oraz wywołanych nimi sytuacji kryzysowych oraz niektórych innych ustaw (Dz.U. 2020, poz. 568, dalej: „Tarcza antykryzysowa”). Dodał on ust. 17 do art. 36 ustawy z 13 października 1998 roku o systemie ubezpieczeń społecznych (Dz.U. 2021, poz. 423 tekst jedn., dalej: „ustawa o s.u.s."), wprowadzając tym samym generalny obowiązek informowania ZUS o zawartych umowach o dzieło. Prima facie techniczny obowiązek wprowadzony w Tarczy antykryzysowej budzi wątpliwości praktyczne, ale co istotniejsze - skłania do postawienia pytań o jego zgodność z wartościami konstytucyjnymi.

\section{Podstawa prawna}

Nowy obowiązek informacyjny został wprowadzony za pomocą następujących mechanizmów. Po pierwsze, art. 36 ustawy o s.u.s. został uzupełniony o ust. 17, zgodnie z którym płatnik składek lub osoba fizyczna zlecająca dzieło informuje ZUS o zawarciu każdej umowy o dzieło, jeżeli umowa taka zostanie zawarta z osobą, z którą nie pozostaje $\mathrm{w}$ stosunku pracy lub jeżeli w ramach takiej umowy nie wykonuje pracy na rzecz pracodawcy, $\mathrm{z}$ którym pozostaje $\mathrm{w}$ stosunku pracy, w terminie do siedmiu dni od dnia zawarcia tej umowy. Po drugie, dane dotyczące umów o dzieło są gromadzone przez ZUS na koncie płatnika składek (art. 45 ust. 1 pkt 1 b ustawy o s.u.s.), a ZUS udostępnia - na żądanie - przedmiotowe dane ministrowi właściwemu do spraw finansów publicznych oraz organom Krajowej Administracji Skarbowej (art. 50 ust. 17 pkt 5 ustawy o s.u.s.). Po trzecie, informację o zawartych umowach o dzieło należy przekazywać na formularzu oznaczonym symbolem RUD, którego wzór został określony w załączniku nr 24 do rozporządzenia Ministra Rodziny i Polityki Społecznej z dnia 20 grudnia 2020 roku w sprawie określenia wzorów zgłoszeń do ubezpieczeń społecznych i ubezpieczenia zdrowotnego, imiennych raportów miesięcznych i imiennych raportów miesięcznych korygujących, zgłoszeń płatnika składek, deklaracji rozliczeniowych i deklaracji rozliczeniowych korygujących, zgłoszeń danych o pracy w szczególnych warunkach lub o szczególnych charakterze, raportów informacyjnych, oświadczeń o zamiarze przekazania raportów informacyjnych, informacji o zawartych umowach o dzieło oraz innych dokumentów (Dz.U. 2020, poz. 2366, dalej: „Rozporządzenie wykonawcze”).

\section{Umowa o dzieło z perspektywy systemu ubezpieczeń społecznych}

Na podstawie umowy o dzieło, uregulowanej w art. 627-647 ustawy z dnia 23 kwietnia 1964 roku - Kodeks cywilny (Dz.U. 2020, poz. 1740 tekst jedn., dalej: „Kodeks cywilny”), przyjmujący zamówienie zobowiązuje się do wykonania oznaczonego dzieła, a zamawiający do zapłaty wynagrodzenia (Gersdorf 2013; wyrok Naczelnego Sądu Administracyjnego z dnia 5 stycznia 2021 roku, II GSK 1522/18, LEX nr 3119192). Istotą umowy o dzieło jako zobowiązania rezultatu jest istnienie po stronie dłużnika powinności osiągnięcia 
specyficznego, z góry określonego rezultatu, przy czym przedmiotowy rezultat to prawny i ekonomiczny skutek oznaczony w treści zobowiązania, nie zaś sama czynność, którą dłużnik powinien podjąć. Odpowiedzialność w takim wypadku wystąpi za brak osiągnięcia umówionego rezultatu. W podziale zobowiązań ze względu na treść i cel świadczenia wyróżnia się - obok zobowiązań rezultatu - zobowiązania starannego działania, których istotą jest powinność dłużnika do dołożenia należytej staranności w zmierzaniu do ustalonego celu, a samo jego osiągnięcie leży poza treścią stosunku prawnego (Wolak 2019, s. 79).

Umowa o dzieło jako umowa rezultatu (Wolak 2019, s. 77-79) co do zasady nie stanowi dla wykonawcy dzieła tytułu do obowiązkowych ubezpieczeń społecznych i ubezpieczenia zdrowotnego. Wyjątkiem są umowy o dzieło zawarte w warunkach określonych w art. 8 ust. 2a ustawy o s.u.s., który rozszerza definicję pracownika poza sferę stosunku pracy ${ }^{1}$. Umowy o dzieło nieobjęte dyspozycją normy z art. 8 ust. 2a ustawy o s.u.s., pomimo że obojętne z perspektywy systemu ubezpieczeń społecznych, nie są obojętne Zakładowi Ubezpieczeń Społecznych. ZUS w ramach przeprowadzanych kontroli weryfikuje bowiem, czy umowa określona pomiędzy stronami jako umowa o dzieło nie jest w rzeczywistości umową zlecenia, umową o świadczenie usług czy umową o pracę (Wolak 2018, s. 24-33) i czy w konsekwencji nie powinna podlegać ubezpieczeniom społecznym i zdrowotnemu. Zakwalifikowanie nawiązanego stosunku prawnego jako stosunku cywilnoprawnego powstałego na podstawie umowy o dzieło bądź innej umowy cywilnoprawnej zależy nie tyle od wybranej dla umowy nazwy, ile od istnienia przedmiotu umowy - dzieła w rozumieniu przepisów Kodeksu cywilnego.

\section{Podmiotowy zakres nowego obowiązku}

Istotą zmian do ustawy o s.u.s. jest wprowadzenie nowego - nieistniejącego dotychczas obowiązku informowania ZUS o zawartych umowach o dzieło.

Zgodnie $\mathrm{z}$ art. 36 ust. 17 ustawy o s.u.s. o zawarciu umowy o dzieło ZUS ma obowiązek poinformować płatnik składek lub osoba fizyczna zlecająca dzieło. Pojęcie płatnika składek zostało zdefiniowane w art. 4 pkt 2 ustawy o s.u.s. Obejmuje ono różnorodną grupę podmiotów, w tym pracodawcę w odniesieniu do pracowników czy ubezpieczonego zobowiązanego do opłacania składek na własne ubezpieczenia społeczne. Na potrzeby niniejszego opracowania istotne jest wskazanie, że pojęciem płatnika składek obejmuje się przede wszystkim jednostkę organizacyjną lub osobę

1 Za pracownika, w rozumieniu art. 8 ust. 2a ustawy o sus, uważa się także m.in. osobę wykonującą pracę na podstawie umowy o dzieło, jeśli umowę taką zawarła $\mathrm{z}$ pracodawcą, $\mathrm{z}$ którym pozostaje $\mathrm{w}$ stosunku pracy, lub jeżeli w ramach takiej umowy wykonuje pracę na rzecz pracodawcy, z którym pozostaje w stosunku pracy. W razie wystąpienia wskazanych okoliczności płatnik składek ma obowiązek zgłosić osobę do ubezpieczeń społecznych i zdrowotnego oraz odprowadzać należne składki. Szerzej o wątpliwościach związanych z ustaleniem, który podmiot powinien być w takiej sytuacji uznany za płatnika (formalny pracodawca czy odbiorca pracy) zob. Gersdorf 2013. 
fizyczną, które pozostają z osobą fizyczną w stosunku prawnym uzasadniającym objęcie tej osoby ubezpieczeniami społecznymi. Poza płatnikiem składek, o zawartych umowach o dzieło ma także obowiązek informować osoba fizyczna zlecająca dzieło. Jakkolwiek należy przychylić się do krytycznej oceny użytego sformułowania „zlecanie dzieła” (Przybyłowicz 2020) ${ }^{2}$, obok płatników składek, zobowiązane do informowania ZUS o zawartych umowach o dzieło są także osoby fizyczne - niebędące płatnikami składek które zamówiły dzieło. Sposób sformułowania przepisu art. 36 ust. 17 in principio ustawy o s.u.s. może wskazywać, że - inaczej niż w odniesieniu do osoby fizycznej zamawiającej dzieło - w przypadku płatnika składek, w każdych okolicznościach to na płatniku będzie spoczywał obowiązek powiadomienia ZUS o zawarciu umowy o dzieło, nawet jeśli płatnik składek będzie wykonawcą dzieła, a nie zamawiającym (Przybyłowicz 2020). Do odmiennych wniosków prowadzi natomiast treść formularza RUD, na którym wykonuje się obowiązek informacyjny. Mianowicie formularz wypełnia i składa do ZUS osoba zamawiająca dzieło. Tym samym, pomimo pewnych wątpliwości na poziomie tekstu przepisów ustawy o s.u.s., należy przyjąć, że obowiązek informacyjny został nałożony nie na wykonawcę dzieła, a wyłącznie na zamawiającego.

W świetle zakresu podmiotowego nowego obowiązku należy postawić pytanie, czy mogą wystąpić podmioty, które nie będą zobowiązane do wykonania obowiązku $\mathrm{z}$ art. 36 ust. 17 ustawy o s.u.s., pomimo że są zamawiającymi dzieło. Stroną umowy o dzieło może być podmiot prawa cywilnego, to jest osoba fizyczna, osoba prawna oraz jednostka organizacyjna niebędąca osobą prawną, której ustawa przyznaje zdolność prawną. Nowy obowiązek informacyjny ciąży w każdym przypadku na osobie fizycznej (która może wystąpić w roli płatnika składek albo w roli osoby zamawiającej dzieło niebędącej płatnikiem składek). Odmiennie obowiązek został ukształtowany w odniesieniu do zamawiających dzieło niebędących osobami fizycznymi, to jest osób prawnych oraz jednostek organizacyjnych niebędących osobami prawnymi, którym ustawa przyznaje zdolność prawną. Mianowicie wskazane podmioty będą zobowiązane do wykonania obowiązku z art. 36 ust. 17 ustawy o s.u.s. tylko wówczas, gdy będą pełniły funkcję płatnika składek. Tym samym osoba prawna - spółka z ograniczoną odpowiedzialnością zatrudniająca jednego pracownika i zamawiająca dziesięć dzieł w miesiącu będzie - jako płatnik składek - zobowiązana do informowania ZUS o zawartych umowach o dzieło, a osoba prawna - spółka z ograniczoną odpowiedzialnością niezatrudniająca żadnego pracownika czy zleceniobiorcy i zamawiająca dwadzieścia dzieł w miesiącu nie będzie miała takiego obowiązku. Przedmiotowa interpretacja znajduje potwierdzenie w oficjalnym stanowisku rządowym (Ministerstwo Rodziny i Polityki Społecznej 2021) oraz stanowisku ZUS, zgodnie z którymi obowiązek zgłaszania umów o dzieło „nie obejmuje podmiotów czy jednostek organizacyjnych (np. stowarzyszeń, fundacji, spółek prawa handlowego, itp.), które nie są płatnikami składek, tj. nie mają obowiązku rejestrować

2 Słusznie wskazuje się w literaturze przedmiotu, że sformułowanie zlecanie odnosi się do umowy zlecenia i nie powinno być używane w odniesieniu do umowy o dzieło. W przypadku umowy o dzieło ustawodawca posługuje się sformułowanie zamawiania dzieła. 
się w ZUS jako płatnicy składek, bo nie zgłaszają nikogo (w tym siebie) do ubezpieczeń społecznych" (Leśniak 2020; ZUS 2021).

Wyłączenie zamawiających, innych niż osoby fizyczne, jeśli nie są płatnikami składek, rodzi pytanie o zgodność takiego rozwiązania z zasadą równego traktowania przez władze publiczne wynikającą z art. 32 ust. 1 Konstytucji Rzeczypospolitej Polskiej z dnia 2 kwietnia 1997 roku (Dz.U. 1997, nr 78, poz. 483 z dnia 16 lipca 1997 roku, dalej: „Konstytucja RP”). Istotą konstytucyjnej zasady równości jest to, by wszystkie podmioty prawne, charakteryzujące się daną cechą istotną $\mathrm{w}$ równym stopniu (wyrok Sądu Najwyższego z dnia 6 grudnia 2012 roku, I PK 128/12, LEX nr 1284749), były traktowane równo, to znaczy według jednakowej miary, bez zróżnicowań zarówno dyskryminacyjnych, jak i faworyzujących (wyrok Sądu Najwyższego z dnia 7 kwietnia 2011 roku, I PK 232/10, LEX nr 1165751; wyrok Sądu Najwyższego z dnia 6 września 2012 roku, II PK 35/12, LEX nr 1619647). Adresatami prawa do równego traktowania wyrażonego w Konstytucji RP są wszystkie podmioty konstytucyjnych praw i wolności, a bezpośrednimi adresatami obowiązków wynikających $\mathrm{z}$ tych przepisów są władze publiczne (Banaszak 2012, s. 226; Bosek, Borysiak 2016, s. 836, 839).

W kontekście konstytucyjnej zasady równości nie jest jasne, dlaczego wprowadzono przedmiotowe rozróżnienie. $Z$ perspektywy deklarowanego celu regulacji brak uzasadnienia dla takiego różnicowania podmiotów zamawiających dzieło. Jeśli celem regulacji jest weryfikacja istnienia obowiązku ubezpieczeń społecznych przez ZUS przez osoby, które są wykonawcami umów o dzieło, wówczas posiadanie przez zamawiającego dzieło statusu płatnika składek nie powinno mieć na to wpływu. Zastosowane kryterium różnicowania nie może natomiast zostać swobodnie wybrane, ale jego wybór musi być racjonalnie uzasadniony, również w kontekście innych zasad konstytucyjnych (wyrok Trybunału Konstytucyjnego z dnia 20 listopada 2002 roku, K 41/02, MP 2002, nr 56, poz. 763).

Literalne brzmienie przepisu art. 36 ust. 17 ustawy o s.u.s. nie przesądza jednoznacznie, czy obowiązkiem mają być objęte wyłącznie osoby fizyczne wykonujące dzieło, czy także wykonawcy dzieła niebędący osobami fizycznymi. Do takiego wniosku prowadzi lektura formularza RUD, na którym należy zgłaszać zawarte umowy o dzieło. Na formularzu należy bowiem podać następujące dane wykonawcy umowy o dzieło, które mogą dotyczyć wyłącznie osoby fizycznej: PESEL albo serię i numer dowodu osobistego, datę urodzenia, imię i nazwisko. Taka interpretacja pozostaje również spójna z celem regulacji, którym jest weryfikacja istnienia obowiązku ubezpieczeń społecznych przez ZUS. Obowiązek ubezpieczeń społecznych może natomiast dotyczyć wyłącznie osób fizycznych.

W świetle językowego brzmienia przepisu art. 36 ust. 17 ustawy o s.u.s. wątpliwości budzi także to, czy z perspektywy nowego obowiązku ma znaczenie obywatelstwo wykonawcy dzieła oraz miejsce wykonania dzieła (na terytorium Rzeczypospolitej Polskiej bądź poza nim). Expressis verbis nowa regulacja nie wskazuje, że swoim zakresem obejmuje wyłącznie wykonawców dzieł - obywateli polskich, którzy wykonują dzieło na terytorium Rzeczypospolitej Polskiej. Jednocześnie ze stanowiska zaprezentowanego przez ZUS wynika, że „,zgłosić do ZUS trzeba tylko umowy o dzieło 
zawierane z obywatelami polskimi lub cudzoziemcami zamieszkującymi w Polsce. Jeżeli obywatel polski lub cudzoziemiec mieszka poza granicami Polski (bez względu na to, czy czasowo, czy na stałe), to zgłosić w ZUS trzeba wyłącznie umowy o dzieło, z których przychód będzie opodatkowany podatkiem dochodowym od osób fizycznych w Polsce" (ZUS 2021). Wydaje się, że brak wskazania przytoczonego wyłączenia w treści przepisu art. 36 ust. 17 ustawy o s.u.s. oznacza, że dopóki nowa regulacja nie zostanie odpowiednio zmieniona, zamawiający dzieło powinien informować ZUS o każdej zawartej umowie o dzieło, $\mathrm{z}$ wyłączeniem jedynie tych umów, które stanowią tytuł do ubezpieczeń społecznych i zdrowotnego.

Podsumowując niniejsze rozważania, zamiast obecnego sformułowania, które - po pierwsze - budzi wskazane wątpliwości interpretacyjne, a po drugie - pozostawia część zamawiających dzieło poza zakresem zastosowania obowiązku, de lege ferenda przepis art. 36 ust. 17 ustawy o s.u.s. mógłby odnosić się nie do płatnika składek lub osoby fizycznej zlecającej dzieło, ale do zamawiającego dzieło do wykonania przez osobę fizyczną.

\section{5. (Nie) każda umowa o dzieło do zgłoszenia}

Nowy obowiązek informacyjny nie dotyczy wszystkich umów o dzieło zawartych od 1 stycznia 2021 roku. Mianowicie obowiązkiem zgłoszenia do ZUS nie są objęte umowy o dzieło zawarte przez płatnika składek/osobę fizyczną zawierającą dzieło ze swoim pracownikiem oraz umowy o dzieło, w ramach których osoba wykonuje pracę na rzecz swojego pracodawcy, pomimo że pracodawca nie jest stroną takiej umowy. Przyczyną odmiennego potraktowania wymienionych umów o dzieło jest regulacja zawarta w art. 8 ust. 2 a ustawy o s.u.s., która wprowadza wyjątek od generalnej zasady niepodlegania umów o dzieło ubezpieczeniom społecznym i zdrowotnemu. Dodatkowo - zgodnie ze stanowiskiem zaprezentowanym przez ZUS - zgłoszeniu nie podlegaja umowy o dzieło wykonywane w ramach działalności gospodarczej, pod warunkiem, że wykonawca dzieła - osoba prowadząca działalność gospodarczą - złożył zamawiającemu oświadczenie, że wykonywane na podstawie umowy usługi wchodzą w zakres prowadzonej przez tę osobę działalności gospodarczej (ZUS 2021), a zatem przychód z umowy będzie przychodem z działalności gospodarczej Tomaszewska (2021, s. 9) wskazuje, że taki wniosek można wywieść z treści załącznika nr 24 do Rozporządzenia wykonawczego.

Tym samym nowy obowiązek informacyjny będzie dotyczył wszystkich umów o dzieło, z których uzyskany przychód nie stanowi dzisiaj podstawy wymiaru składek na ubezpieczenia społeczne i ubezpieczenie zdrowotne. W świetle deklarowanego celu nowej regulacji jest to rozwiązanie zrozumiałe z tego względu, że ZUS już przed wejściem w życie nowych przepisów miał wiedzę o umowach o dzieło stanowiących tytuł do ubezpieczeń społecznych, a przedmiotowe umowy o dzieło podlegały ubezpieczeniom społecznym i zdrowotnemu na zasadach właściwych dla umów o pracę bądź w ramach działalności gospodarczej. Tym samym nowy obowiązek może zostać ograniczony do tych 
umów o dzieło, o zawarciu których ZUS dotychczas nie mógł mieć wiedzy, a o których dowiadywał się przy okazji prowadzonych u płatników składek kontroli.

\section{Realizacja nowego obowiązku}

Podmiot zamawiający dzieło - adresat normy prawnej z art. 36 ust. 17 ustawy o s.u.s. ma obowiązek informować ZUS o zawarciu umowy o dzieło podlegającej zgłoszeniu w terminie do siedmiu dni od daty jej zawarcia. Zgłoszenia należy dokonać na formularzu oznaczonym symbolem RUD.

Konsekwencje wynikające z niedopełnienia obowiązku przez płatników składek określają przepisy wykroczeniowe ustawy o s.u.s. Zgodnie z art. 98 ust. 1 pkt 2 - kto jako płatnik składek albo osoba obowiązana do działania w imieniu płatnika nie zgłasza danych wymaganych ustawą lub zgłasza dane nieprawdziwe podlega karze grzywny do pięciu tysięcy złotych (Kuśmierczyk 2021). Analogiczna regulacja nie istnieje w przypadku niedopełnienia obowiązku przez osobę fizyczną niebędącą płatnikiem, która zamówiła dzieło u innej osoby fizycznej. W związku z tym należałoby przyjąć, że brak poinformowania ZUS nie będzie się wiązał z negatywnymi konsekwencjami dla takiego podmiotu (Przybyłowicz 2020; przeciwnie: Tomaszewska 2021, s. 10).

\section{Informacje niezbędne w demokratycznym państwie prawnym}

Przy okazji zmian mających na celu wprowadzenie rozwiązań związanych z zapobieganiem, przeciwdziałaniem i zwalczaniem COVID-19, innych chorób zakaźnych oraz wywołanych nimi sytuacji kryzysowych po raz kolejny poszerzone zostały kompetencje ZUS, który począwszy od 1 stycznia 2021 roku otrzymuje o umowach o dzieło - zasadniczo obojętnych z perspektywy systemu ubezpieczeń społecznych - szczegółowe dane, których nie posiada nawet w odniesieniu do umów o pracę czy umów zlecenia stanowiących tytuł do ubezpieczeń społecznych i zdrowotnego.

Skłania to do analizy nowej regulacji z perspektywy konstytucyjnego prawa do ochrony życia prywatnego wynikającego z art. 47 Konstytucji RP, które wywodzi się z zasady demokratycznego państwa prawnego, a którego istotą jest autonomia rozumiana jako obszar wolny od ingerencji zewnętrznej (Safjan 2007). Autonomia jednostki stanowi istotę godności człowieka (wyrok Trybunału Konstytucyjnego z dnia 2 marca 1994 roku, W 9/93, Dz.U. 1994, nr 45, poz. 184; Garlicki 2003, s. 7; Sobczyk 2014, s. 37), która jest źródłem wszystkich konstytucyjnych praw (w tym wolności). Godność - jako przyrodzona i niezbywalna cecha człowieka (Sarnecki 2002, s. 63; Radwański 2008, s. 7-8; Sanetra 2013, s. 13) - jest nienaruszalna, a jej poszanowanie i ochrona jest obowiązkiem władz publicznych (Drozd 2010, s. 18; Garlicki 2013; Sobczyk 2003, s. 377). Wyrazem autonomii w prawie prywatnym jest swoboda kształtowania treści stosunków prawnych między podmiotami prawa, a w prawie publicznym możliwość żądania od organów państwa 
respektowania autonomii jednostki przez określone działania pozytywne - przyznanie gwarancji materialnych, oraz negatywne - powstrzymywanie się od zachowań wkraczających w sferę zastrzeżoną dla autonomii (Safjan 2007).

Jednym z przejawów prawa do ochrony życia prywatnego z art. 47 Konstytucji RP $\mathrm{w}$ zakresie dotyczącym autonomii informacyjnej jednostki - jest prawo do ochrony danych osobowych wynikające z art. 51 Konstytucji RP (Safjan 2007; Wiliński 2011; Florczak-Wątor 2019), które stanowi lex specialis do regulacji zawartej w art. 47 Konstytucji RP (Sarnecki 2016; Florczak-Wątor 2019). Autonomia informacyjna jednostki rozumiana jest jako wolność jednostki w zakresie udostępniania informacji jej dotyczących oraz dopuszczalność ingerencji w tę wolność przez władze publiczne (Sarnecki 2016; Florczak-Wątor 2019) i wysuwa się na pierwszy plan jako składnik chronionej prywatności w orzecznictwie Trybunału Konstytucyjnego (Safjan 2007).

Dopuszczona w art. 51 Konstytucji RP możliwość ograniczenia autonomii informacyjnej jednostki musi być wprowadzona w ustawie (ust. 1; zob. szerzej fragment opracowania Szczegółowe upoważnienie do wydania Rozporzadzenia) oraz musi spełniać wymóg niezbędności (ust. 2).

Pomimo że przepis art. 51 ust. 2 Konstytucji RP samodzielnie określa granice ingerencji władz publicznych w autonomię informacyjną jednostki, jego wykładni należy dokonywać w kontekście przyjętej w art. 31 ust. 3 Konstytucji RP zasady proporcjonalności. Funkcją mechanizmu proporcjonalności jest doprecyzowanie stosowanej klauzuli generalnej zawartej w art. 51 ust. 2 Konstytucji RP, która dopuszcza gromadzenie i przetwarzanie informacji o obywatelach w granicach niezbędnych w demokratycznym państwie prawnym (Safjan 2007). Artykuł 31 ust. 3 Konstytucji RP określa przesłanki, których spełnienie jest konieczne do wprowadzania ograniczeń praw i wolności jednostki. Po pierwsze, wprowadza ustawowy wymóg dla ograniczeń. Po drugie, ograniczenia te mogą być wprowadzone tylko wtedy, gdy są konieczne w demokratycznym państwie prawnym dla jego bezpieczeństwa lub porządku publicznego, ochrony środowiska, zdrowia i moralności publicznej, albo wolności i praw innych osób. Po trzecie, nakazuje szanowanie zasady proporcjonalności oraz zakazuje naruszania istoty praw i wolności (Garlicki 2003; Safjan 2007). Zasadnicze znaczenie przypisuje się zasadzie proporcjonalności rozumianej jako możliwość wprowadzania ograniczeń praw i wolności wyłącznie w stopniu niezbędnym (Sobczyk 2014, s. 101).

W celu zachowania zasady proporcjonalności konieczna jest twierdząca odpowiedź na następujące pytania: a) czy wprowadzona regulacja jest w stanie doprowadzić do zamierzonych przez nią skutków, to jest, czy spełniona jest zasada przydatności; b) czy regulacja ta jest niezbędna dla ochrony interesu publicznego, z którym jest powiązana, to jest, czy spełniona jest zasada konieczności, oraz c) czy efekty wprowadzonej regulacji pozostają w proporcji do ciężarów nakładanych na obywatela, to jest, czy spełniona jest zasada proporcjonalności sensu stricto (wyrok Trybunału Konstytucyjnego z dnia 12 grudnia 2005 roku, K 32/04, Dz.U. 2005, nr 250, poz. 2116).

Wymóg niezbędności jako przesłanka wartościująca, niezdefiniowana samodzielnie w Konstytucji RP, została doprecyzowana w bogatym orzecznictwie Trybunału Konstytucyjnego. Za niezbędne uznaje się wyłącznie te informacje, które warunkują (mają charakter 
conditio sine qua non) możliwość realizacji przyznanych organowi kompetencji, nie mogą być one zbierane „na wszelki wypadek” (Florczak-Wątor 2019). Wśród wyznaczników „niezbędności” wskazuje się w szczególności brak w systemie innych, charakteryzujących się mniejszą dolegliwością środków pozwalających na osiągnięcie podobnego skutku (Safjan 2007). Naruszenie tej sfery prywatności musi w pełni odpowiadać standardom demokratycznego państwa prawa, co oznacza, że ani względy celowości, ani wygody władzy nie uzasadniają takiego naruszenia (wyrok Trybunału Konstytucyjnego z dnia 11 maja 2007 roku, K 2/07, Dz.U. 2007, nr 85, poz. 571; wyrok Trybunału Konstytucyjnego z dnia 17 czerwca 2008 roku, K 8/04, Dz.U. 2008, nr 110, poz. 707; wyrok Trybunału Konstytucyjnego z dnia 20 listopada 2002 roku, K 41/02, MP 2002, nr 56, poz. 763).W takim przypadku należy zastosować inne metody, chociażby trudniejsze w stosowaniu i bardziej uciążliwe dla władzy publicznej. Marek Safjan (2007) zwraca uwagę, że z orzecznictwa konstytucyjnego wynika w sposób niebudzący wątpliwości, że samo istnienie ważnego interesu publicznego nie jest per se wystarczającym motywem ingerowania/limitowania wolności jednostek. W tym kontekście zbędnymi będą te informacje, którymi organy administracji publicznej mogą być, co prawda, zainteresowane, ale bez których mogą one działać i wypełniać swoje kompetencje (Fleszer 2008). W orzecznictwie Trybunału Konstytucyjnego wskazuje się, że instrumentem typowym dla współczesnych czasów, po który władza publiczna chętnie sięga, są naruszenia autonomii informacyjnej przez żądanie niekoniecznych, ale wygodnych czy użytecznych dla władzy publicznej informacji o jednostce (wyrok Trybunału Konstytucyjnego z dnia 20 listopada 2002 roku, K 41/02, MP 2002, nr 56, poz. 763).

$\mathrm{W}$ uzasadnieniu projektu ustawy wskazano, że celem zaproponowanej zmiany jest umożliwienie ZUS weryfikowania istnienia obowiązku ubezpieczeń społecznych osób wykonujących umowy nazwane umowami o dzieło (uzasadnienie rządowego projektu ustawy o zmianie ustawy o szczególnych rozwiązaniach związanych z zapobieganiem, przeciwdziałaniem i zwalczaniem COVID-19, innych chorób zakaźnych oraz wywołanych nimi sytuacji kryzysowych oraz niektórych innych ustaw, druk sejmowy nr 299, Sejm IX kadencji). Weryfikacja istnienia obowiązku ubezpieczeń społecznych przez ZUS odbywa się w procedurze kontroli wykonywania zadań i obowiązków w zakresie ubezpieczeń społecznych przeprowadzanej przez inspektorów kontroli ZUS na zasadach wynikających z art. 86 i n. ustawy o s.u.s. Jak wskazano, umowy o dzieło co do zasady nie stanowią tytułu do ubezpieczeń społecznych i zdrowotnego, chyba że zostanie uznane, iż - pomimo nazwy zawartej umowy - strony łączy nie umowa o dzieło, ale umowa zlecenia, umowa o świadczenie usług czy umowa o pracę (Gersdorf 2013). Przed 1 stycznia 2021 roku ZUS otrzymywał informacje wyłącznie o umowach o dzieło, do których zastosowanie ma art. 8 ust. 2a ustawy o s.u.s. Zakwestionowanie zatem innych umów o dzieło było możliwe, jeśli przy okazji przeprowadzanej kontroli ZUS posiadł wiedzę, że dany płatnik zawiera umowy o dzieło.

Do osiągnięcia przedstawionego celu nowej regulacji wystarczające jest przekazanie do ZUS informacji, że umowa o dzieło została zawarta z osobą fizyczną. Po otrzymaniu przedmiotowej informacji ZUS dysponuje kompetencjami kontrolnymi, które umożliwiają 
weryfikację, czy zawarta umowa powinna stanowić tytuł do ubezpieczeń społecznych i zdrowotnego.

Faktycznym celem nowej regulacji było nie tyle umożliwienie weryfikowania istnienia obowiązku ubezpieczeń społecznych osób wykonujących umowy nazwane umowami o dzieło, ile ułatwienie działania ZUS w zakresie kontroli umów o dzieło, polegające na kontrolowaniu wyłącznie tych umów o dzieło, w stosunku do których szanse skutecznego zakwestionowania będą wyższe (na podstawie przekazanych danych dotyczących przedmiotu umowy, daty rozpoczęcia i zakończenia wykonywania dzieła). W ten sposób wszczynane przez ZUS kontrole byłyby bardziej efektywne i tańsze z perspektywy finansów publicznych.

Tym samym jednak nałożony obowiązek zgłaszania do ZUS szczegółowych danych dotyczących każdej umowy o dzieło nie spełnia drugiej przesłanki proporcjonalności, to jest konieczności użytego środka do osiągnięcia zamierzonego celu wskazanego w uzasadnieniu badanej ustawy (umożliwienie weryfikacji obowiązku zgłoszenia do ubezpieczeń). Ani niskie koszty, ani łatwość posługiwania się danym środkiem nie są bowiem wystarczające, aby spełniony mógł być test niezbędności (wyrok Trybunału Konstytucyjnego z dnia 12 grudnia 2005 roku, K 32/04, Dz.U. 2005, nr 250, poz. 2116). Nie jest spełniona także przesłanka jak najmniejszej uciążliwości dla jednostki, którą wymusza zasada proporcjonalności. Nałożenie na jednostki zamawiające dzieło obowiązku przekazywania do ZUS szczegółowych danych dotyczących zawartej umowy o dzieło w istocie stanowi zmuszenie jednostki do wyręczenia ZUS w zbieraniu informacji w ramach procedur kontrolnych.

Podsumowując poczynione rozważania, należy uznać, że nowy obowiązek nakłada na zobowiązanych uciążliwość, która wprawdzie ułatwia działanie organu administracji publicznej, ale która nie jest uzasadniona celem regulacji i jako taka rodzi istotne wątpliwości z perspektywy konstytucyjnej zasady proporcjonalności (wyrok Trybunału Konstytucyjnego z dnia 20 listopada 2002 roku, K 41/02, MP 2002, nr 56, poz. 763). W sposób wyraźny widać to zwłaszcza w odniesieniu do konieczności podania danych dotyczących terminu rozpoczęcia i zakończenia dzieła. Z istoty umowy o dzieło wynika, że strony muszą przewidzieć upływ pewnego czasu na wykonanie zamówienia, ale umowa o dzieło nie może być określana jako typowa umowa zawarta na czas oznaczony, ale jako specyficzny rodzaj umowy terminowej (wyrok Sądu Apelacyjnego w Białymstoku z dnia 18 czerwca 2013 roku, I ACa 232/13, LEX nr 1498861). Zobowiązany do zgłoszenia umowy o dzieło ma nie tylko obowiązek wskazania w formularzu RUD terminu zakończenia dzieła, ale także - zgodnie ze stanowiskiem prezentowanym przez ZUS - aktualizowania tych danych w razie ich zmiany.

De lege ferenda w celu zachowania zgodności nowego obowiązku z konstytucyjnym prawem do ochrony życia prywatnego należałoby ograniczyć zakres danych zgłaszanych do ZUS wyłącznie do informacji, że umowa o dzieło została zawarta z osobą fizyczną. Informacja taka mogłaby być zgłaszana nie każdorazowo po zawarciu umowy o dzieło, ale zbiorczo, raz na kwartał czy rok. W ten sposób spełnione byłyby zarówno przesłanki niezbędności oraz proporcjonalności. 


\section{Szczegółowe upoważnienie do wydania Rozporządzenia wykonawczego}

Niezależnie od samych wątpliwości odnośnie do tego, czy w demokratycznym państwie prawnym gromadzenie szczegółowych informacji o wszystkich wykonawcach umów o dzieło, którzy są osobami fizycznymi, i umowach o dzieło, których są stronami, jest niezbędne w świetle art. 51 ust. 2 Konstytucji, zgodnie z art. 51 ust. 1 w zw. $z$ art. 51 ust. 5 Konstytucji RP, nikt nie może być zobowiązany inaczej niż na podstawie ustawy do ujawnienia informacji dotyczących jego osoby, a zasady i tryb gromadzenia przedmiotowych informacji określa ustawa. Pomimo że obowiązek powiadomienia ZUS o zawartej umowie o dzieło wprowadza ustawa o s.u.s., zakres danych, które mają być przekazane, wyznacza nie ustawa, lecz Rozporządzenie wykonawcze.

Zgodnie z art. 92 ust. 1 w zw. $\mathrm{z}$ art. 87 ust. 1 Konstytucji RP rozporządzenia stanowiące jedno ze źródeł powszechnie obowiązującego prawa Rzeczypospolitej Polskiej są wydawane na podstawie szczegółowego upoważnienia zawartego w ustawie i w celu jej wykonania. Szczegółowość musi wystąpić pod kątem podmiotowym, przedmiotowym i treściowym (wyrok Trybunału Konstytucyjnego z dnia 19 czerwca 2008 roku, P 23/07, Dz.U. 2008, nr 116, poz. 740). Zgodnie z $\$ 63$ rozporządzenia Prezesa Rady Ministrów z dnia 20 czerwca 2002 roku w sprawie „Zasad techniki prawodawczej” (Dz.U. 2016, poz. 283 tekst jedn., dalej: „Zasady techniki prawodawczej”) przedmiotowe upoważnienie powinno określać organ właściwy do wydania rozporządzenia, rodzaj aktu, zakres spraw przekazanych do uregulowania oraz wytyczne dotyczące treści aktu.

Organem właściwym do wydania rozporządzenia są organy wskazane w Konstytucji RP jako posiadające kompetencję do wydawania powszechnie obowiązujących podustawowych aktów prawnych. Określenie w ustawie zakresu spraw przekazanych do uregulowania rozporządzeniem, które realizuje wymóg szczegółowości pod względem przedmiotowym, ma gwarantować zachowanie niezbędnego związku treści rozporządzenia z celem i tematyką ustawy (Radziewicz 2019). W końcu szczegółowość treściowa oznacza wymóg zawarcia w ustawie wytycznych dotyczących treści (materialnego kształtu) aktu wykonawczego. Innymi słowy, upoważnienie do wydania rozporządzenia powinno być skonstruowane w taki sposób, aby na jego podstawie możliwa była odpowiedź na trzy pytania: kto ma prawo wydania aktu, co w tym akcie ma zostać uregulowane i jak mają być uregulowane dane kwestie (wyrok Trybunału Konstytucyjnego z dnia 19 czerwca 2008 roku, P 23/07, Dz.U. 2008, nr 116, poz. 740).

Im bardziej dana regulacja wkracza w zakres praw podstawowych jednostki, tym pełniejsza powinna być regulacja ustawowa (Kędziora 2009; Skwara 2010). Z perspektywy szczegółowości upoważnienia za niewłaściwe uznaje się posługiwanie się formułami ogólnymi (na przykład formułą „zasad i trybu”) bez odpowiedniego wskazania znaczenia tych pojęć w samej ustawie ( $\$ 65$ Zasad techniki prawodawczej; Kędziora 2009; Skwara 2010). Jeśli przepisy zawarte w rozporządzeniu służące wykonaniu ustawy wykraczają poza zakres upoważnienia, oznacza to naruszenie zasad umocowania i funkcji aktu wykonawczego (Kędziora 2009). Rozporządzenie nie powinno uzupełniać ustawy, 
rozbudowywać przesłanek zrealizowania jakiejś normy prawnej określonej w ustawie lub takich elementów procedury, które nie odpowiadają ustawowym założeniom (Skwara 2010), a powinno jedynie zawierać regulację, która funkcjonalnie uzupełnia ustawę (wyrok Trybunału Konstytucyjnego z dnia 19 czerwca 2008 roku, P 23/07, Dz.U. 2008, nr 116, poz. 740; Wronkowska 2004, s. 230).

Wymóg ustanowienia rozporządzenia w celu wykonania ustawy należy także odczytywać jako nakaz powiązania rozporządzenia z treścią ustawy (Skwara 2010). Ograniczenie swobody kształtowania treści rozporządzenia w tym zakresie potwierdza jego instrumentalny charakter względem ustawy (Bałaban 2003). Rozporządzenie powinno realizować ten sam cel, który przyświeca ustawie. W przeciwnym razie dochodzi do wykroczenia poza zakres delegacji ustawowej. Jednocześnie przy interpretacji zakresu upoważnienia z perspektywy realizacji celu ustawy należy pamiętać, że przepisy kompetencyjne podlegają ścisłej wykładni i jakakolwiek wykładnia rozszerzająca jest zakazana (Skwara 2010).

Brak treści ustawowych, które mogłyby pełnić funkcję wytycznych dotyczących treści aktu, jest wystarczające do uznania niekonstytucyjności delegacji ustawowej, nawet jeśli spełnia ona wymóg szczegółowości pod względem podmiotowym i przedmiotowym. Niekonstytucyjność upoważnienia ustawowego skutkuje natomiast utratą mocy obowiązującej przez przepis, w którym przedmiotowe upoważnienie jej zawarte. Los przepisu dzieli natomiast rozporządzenie wykonawcze (wyrok Trybunału Konstytucyjnego z dnia 19 czerwca 2008 roku, P 23/07, Dz.U. 2008, nr 116, poz. 740; wyrok Trybunału Konstytucyjnego z dnia z 26 października 1999 roku, K 12/99, Dz.U. 1999, nr 91, poz. 1042). W przypadku uznania, że upoważnienie spełnia wymóg pod względem podmiotowym, przedmiotowym i treściowym, należy ocenić, czy zakres danych, których podanie wymusza treść formularza oznaczonego symbolem RUD, jest zgodny z przedmiotowym upoważnieniem (realizuje cel ustawy).

Upoważnienie do wydania Rozporządzenia wykonawczego zawarto w art. 49 ust. 2 pkt 9 ustawy o s.u.s., zgodnie z którym minister właściwy do spraw zabezpieczenia społecznego, $w$ drodze rozporządzenia, określa wzory informacji o zawartych umowach $o$ dzieło, o których mowa w art. 36 ust. 17 ustawy o s.u.s. Upoważnienie określa zatem organ właściwy do wydania aktu (ministra właściwego do spraw zabezpieczenia społecznego), akt (rozporządzenie) oraz zakres spraw przekazanych do uregulowania (określenie wzoru informacji o zawartych umowach o dzieło, o których mowa w art. 36 ust. 17 ustawy o s.u.s.). Jako spełniony należy zatem uznać wymóg szczegółowości pod względem podmiotowym i przedmiotowym. Ustawa o s.u.s. w art. 49 ust. 2 pkt 9 nie zawiera bardziej szczegółowych wytycznych, co skłania do postawienia pytania o realizację wymogu szczegółowości pod względem treściowym.

Przepis art. 92 ust. 1 Konstytucji RP nie definiuje pojęcia wytycznych dotyczących treści aktu.W $\$ 66$ Zasad techniki prawodawczej wskazano, że wytyczne dotyczące treści rozporządzenia są wskazówkami wyznaczającymi jego treść lub sposób ukształtowania treści. Merytorycznych wytycznych (dotyczących materialnego kształtu aktu) nie mogą zastąpić wskazówki dotyczące spraw proceduralnych, za które przykładowo można uznać 
określenie, że ustanowienie rozporządzenia następuje w uzgodnieniu z innym podmiotem. Określenie formy wytycznych pozostawiono uznaniu ustawodawcy. W świetle $\$ 66$ Zasad techniki prawodawczej wytyczne mogą obejmować w szczególności: rozstrzygnięcia, których nie wolno przewidzieć w rozporządzeniu, granice, w jakich muszą się zmieścić rozstrzygnięcia rozporządzenia, wymagania, jakim mają odpowiadać rozwiązania przyjęte w rozporządzeniu, cele, jakie mają zostać osiągnięte przez rozporządzenie, i okoliczności, które należy uwzględnić (wyrok Trybunału Konstytucyjnego z dnia 19 czerwca 2008 roku, P 23/07, Dz.U. 2008, nr 116, poz. 740). Stopień szczegółowości wytycznych powinien być uzależniony od rodzaju spraw przekazanych do uregulowania - jeśli sprawy dotyczą sytuacji prawnej obywateli, wytyczne powinny być bardziej szczegółowe.

$\mathrm{W}$ analizowanym przypadku wytyczne dotyczące treści powinny obejmować wskazanie (określenie) danych dotyczących zawartych umów o dzieło, do których przekazania będą zobowiązani zamawiający dzieło. Przepis art. 49 ust. 2 pkt 9 ustawy o s.u.s. nie określa danych, które należy przekazać, a jedynie odwołuje się do art. 36 ust. 17 ustawy o s.u.s., który wprowadza do polskiego porządku prawnego nowy obowiązek. Trybunał Konstytucyjny w swoim orzecznictwie wskazał, że wytyczne nie muszą być zawarte w przepisie formułującym upoważnienie do wydania rozporządzenia. Możliwe jest ich zamieszczenie w innych przepisach ustawy, pod warunkiem, że pozwala to na ich zrekonstruowanie (Bałaban 2003). Wątpliwość co do tej zasady wyraził Bartosz Skwara, który stwierdził, że możliwość rekonstrukcji normy prawnej zawierającej wytyczne na podstawie całej treści ustawy upoważniającej jest niepokojąca (Skwara 2010).

Sformułowanie obowiązku w art. 36 ust. 17 ustawy o s.u.s. umożliwia odkodowanie wytycznych dotyczących treści Rozporządzenia wykonawczego. Mianowicie w celu wykonania obowiązku informacyjnego niezbędne jest podanie stron umowy o dzieło (w celu weryfikacji, że umowa została zawarta poza dyspozycją art. 8 ust. 2a ustawy o s.u.s.) oraz daty zawarcia umowy (obowiązek zgłaszania umów o dzieło dotyczy wyłącznie umów zawartych od 1 stycznia 2021 roku, a sam obowiązek należy wykonać w terminie do siedmiu dni od zawarcia umowy). Ustawa o s.u.s. nie wskazuje, jakie dane poza samym faktem zawarcia umowy o dzieło oraz jej stronami zamawiający dzieło ma przekazać do ZUS. Takie dodatkowe informacje pojawiają się dopiero w treści Rozporządzenia wykonawczego. Zgodnie z treścią formularza ZUS RUD do ZUS zamawiający dzieło przekazuje następujące dane: a) dane zamawiającego dzieło (to jest NIP, REGON bądź PESEL, imię i nazwisko lub nazwę skróconą, adres, numer telefonu i adres e-mail); b) dane wykonawcy umowy o dzieło (to jest PESEL albo serię i numer dowodu osobistego, datę urodzenia, imię i nazwisko, adres zamieszkania i adres do korespondencji, numer telefonu i adres e-mail) oraz c) dane dotyczące zawartej umowy o dzieło (to jest datę zawarcia umowy, datę rozpoczęcia wykonywania dzieła, datę zakończenia wykonywania dzieła oraz przedmiot umowy).

Zgodnie ze stanowiskiem Ministerstwa Rodziny i Polityki Społecznej przekazywane dane zawierają wyłącznie ogólne informacje dotyczące zawartej umowy. W celu wykonania ustawy podanie jakichkolwiek dodatkowych danych (poza stronami umowy 
i datą jej zawarcia) nie jest jednak konieczne. Nawet w przypadku przyjęcia, że - zgodnie $\mathrm{z}$ informacją zawartą $\mathrm{w}$ uzasadnieniu projektu ustawy - celem nowego obowiązku jest weryfikacja istnienia obowiązku ubezpieczeń społecznych przez ZUS, podanie takich dodatkowych danych nie umożliwia takiej weryfikacji, gdyż w tym celu konieczne jest przeprowadzenie kontroli przez ZUS.

W świetle obecnej treści upoważnienia ustawowego do określania treści formularza ZUS RUD - należy uznać, że wymóg podania dodatkowych danych powinien być wprost wskazany w ustawie, podobnie jak w przypadku art. 36 ust. 10 ustawy o s.u.s. określającego dane, które należy podać w zgłoszeniu osoby do ubezpieczeń. Nie zniweluje to wątpliwości przedstawionych w pierwszej części niniejszego opracowania dotyczących autonomii informacyjnej jednostki, ale zapewni zgodność regulacji z art. 92 ust. 1 Konstytucji RP.

\section{Uwagi końcowe}

We współczesnym społeczeństwie informacyjnym, w którym człowiek to „osoba transparentna dla otoczenia we wszystkich przejawach swojej egzystencji i w każdym okresie swojego życia" (Safjan 2007), konieczność zgłoszenia zawartych umów o dzieło może jawić się jako techniczny obowiązek, który może zostać wykonany w kilka chwil przez złożenie wypełnionego i podpisanego profilem zaufanym formularza ZUS RUD na koncie płatnika ZUS PUE.

Prima facie techniczny obowiązek skutkuje jednak przekazaniem do ZUS istotnych danych o stosunkach prawnych zasadniczo obojętnych z perspektywy systemu ubezpieczeń społecznych, których zakres wyznacza nie ustawa, ale akt podustawowy.

Regulacja wprowadza nową powinność, która jednocześnie nie wiąże się z żadną nową daniną publiczną, a jednie ułatwia przeprowadzanie kontroli ZUS. Nie ulega wątpliwości, że w celu ochrony systemu prawa ubezpieczeń społecznych kwestionowanie umów o dzieło wykonywanych w warunkach charakterystycznych dla umowy o pracę, umowy zlecenia $\mathrm{i}$ umowy o świadczenie usług jest potrzebne i pożądane. Ustawodawca ma jednak prawo i obowiązek zwalczania negatywnych zjawisk przez nadawanie takich uprawnień organom kontroli, które będą miały bezpośredni wpływ na zwiększenie sprawności działań kontrolnych, przy jednoczesnym pozostawaniu w zgodzie z zasadami Konstytucji RP (wyrok Trybunału Konstytucyjnego z dnia 20 czerwca 2005 roku, K 4/04, Dz.U. 2005, nr 124, poz. 1042; Safjan 2007).

W tym kontekście istotne wątpliwości budzi sposób wprowadzenia nowego obowiązku oraz zakres danych przekazywanych do ZUS. Pod pozorem działań antykryzysowych wprowadzono w Tarczy antykryzysowej obowiązek, który z jej celem ma niewiele wspólnego ${ }^{3}$. Co więcej, analogicznych danych, których obowiązek zgłoszenia wynika nie z ustawy, a z Rozporządzenia wykonawczego, ZUS nie gromadzi ani w odniesieniu

3 Analogiczne rozwiązania przyjęto przykładowo w przypadku art. 15 gf Tarczy antykryzysowej 1.0, która umożliwia wypowiedzenie umów o zakazie konkurencji za siedmiodniowym uprzedzeniem. 
do umów o pracę, ani umów cywilnoprawnych, które stanowią tytuł do obowiązkowych ubezpieczeń społecznych i ubezpieczenia zdrowotnego.

\section{Bibliografia}

Bałaban A. (2003) Polskie problemy ustrojowe. Konstytucja, źródła prawa, samorzad terytorialny, prawa człowieka, LEX.

Banaszak B. (2012) Konstytucja Rzeczypospolitej Polskiej, Warszawa.

Bosek L., Borysiak W. (2016) [w:] M. Safjan, L. Bosek (red.), Konstytucja RP, t. 1: Komentarz do art. 1-86, Warszawa.

Drozd A. (2010) Wykładnia w zgodzie z Konstytucja w dziedzinie prawa pracy, „Przegląd Sądowy", nr 2.

Fleszer D. (2008) Zakres przetwarzania danych osobowych $w$ działalności gospodarczej, LEX. Florczak-Wątor M. (2019) [w:] P. Tuleja (red.), Konstytucja Rzeczypospolitej Polskiej. Komentarz, LEX.

Garlicki L. (2003) [w:] L. Garlicki (red.), Konstytucja Rzeczypospolitej Polskiej. Komentarz, t. 3, Warszawa.

Gersdorf M. (2013) Prawo zatrudnienia, LEX.

Kędziora P. (2009) [w:] A. Malinowski (red.), Zarys metodyki pracy legislatora. Ustawy - akty wykonawcze - prawo miejscowe, LEX.

Kuśmierczyk M. (2021) Zmiany w ustawie o systemie ubezpieczeń społecznych wprowadzające obowiązek zgłaszania do ZUS informacji o zawarciu umowy o dzieło, „Biuletyn Instytutu Studiów Podatkowych", nr 1, Legalis.

Leśniak G.J. (2020) ZUS: Od stycznia 2021 r. trzeba będzie rejestrować umowy o dzieło, https://www. prawo.pl/kadry/kto-bedzie-musial-zglosic-umowe-o-dzielo-do-zus-po-1-stycznia, 505460. html (dostęp: 18 kwietnia 2021).

Ministerstwo Rodziny i Polityki Społecznej, Obowiązek zgłaszania do ZUS umów o dzieło zawieranych od 1 stycznia 2021 r., https://www.gov.pl/web/rodzina/obowiazek-zglaszania-do-zus-umow-o-dzielo-zawieranych-od-1-stycznia-2021-r (dostęp: 18 kwietnia 2021).

Przybyłowicz A. (2020) [w:] K.W. Baran (red.), Komentarz do niektórych przepisów ustawy z dnia 31 marca 2020 r. o zmianie ustawy o szczególnych rozwiązaniach związanych z zapobieganiem, przeciwdziałaniem i zwalczaniem COVID-19, innych chorób zakaźnych oraz wywołanych nimi sytuacji kryzysowych oraz niektórych innych ustaw [w:] Tarcza antykryzysowa 1.0-4.0, ustawa o dodatku solidarnościowym i inne regulacje, jako szczególne rozwiązania w prawie pracy, prawie urzędniczym i prawie ubezpieczeń społecznych zwiąane z COVID-19. Komentarz, LEX.

Radwański Z. (2008) [w:] Z. Radwański (red.), System Prawa Prywatnego, t. 2: Prawo cywilne część ogólna, Warszawa.

Radziewicz P. (2019) [w:] P. Tuleja (red.), Konstytucja Rzeczypospolitej Polskiej. Komentarz, LEX. Safjan M. (2007) Wyzwania dla państwa prawa, LEX.

Sanetra W. (2013) Ogólnie o aksjologicznych podstawach prawa pracy, referat wygłoszony podczas XIX Zjazdu Katedr i Zakładów Prawa Pracy w dniach 15-17 maja 2013 roku.

Sarnecki P. (2016) [w:] L. Garlicki, M. Zubik (red.), Konstytucja Rzeczypospolitej Polskiej. Komentarz, t. 2, LEX. 
Sarnecki P. (red.) (2002) Prawo konstytucyjne RP, Warszawa.

Skwara B. (2010) Rozporzadzenie jako akt wykonawczy do ustawy w polskim prawie konstytucyjnym, LEX.

Sobczyk A. (2013) Ograniczenia praw i wolności konstytucyjnych pracownika w prawie pracy zarys problematyki [w:] B. Cudowski, J. Iwulski (red.), Z aktualnych zagadnień prawa pracy i zabezpieczenia społecznego. Ksiega jubileuszowa Profesora Waleriana Sanetry, Białystok.

Sobczyk A. (2014) Prawo i człowiek pracujący - między ochrona godności a równości [w:] M. Skąpski, K. Ślebzak (red.), Aksjologiczne podstawy prawa pracy i ubezpieczeń społecznych, Poznań.

Tomaszewska B. (2021) [w:] B. Tomaszewska, M. Kostrzewa, G. Łyjak, P. Ziółkowki, Zgłoszenie do ZUS umowy o dzieło - nowy obowiązek od 1 stycznia 2021 r., LEX.

Uzasadnienie rządowego projektu ustawy o zmianie ustawy o szczególnych rozwiązaniach związanych z zapobieganiem, przeciwdziałaniem i zwalczaniem COVID-19, innych chorób zakaźnych oraz wywołanych nimi sytuacji kryzysowych oraz niektórych innych ustaw (2020), druk sejmowy nr 299, Sejm IX kadencji.

Wiliński P. (2011) Proces karny w świetle Konstytucji, LEX.

Wolak G. (2018) Umowa mająca za przedmiot sprzątanie - umowa o dzieło czy umowa o świadczenie usług, „Praca i Zabezpieczenie Społeczne”, nr 5.

Wolak G. (2019) Umowa o dzieło jako zobowiązanie rezultatu, „Studia Prawnicze. Rozprawy i materiały", nr 1.

Wronkowska S. (2004) [w:] S. Wronkowska, M. Zieliński, Komentarz do zasad techniki prawodawczej, Warszawa.

ZUS (2021) Pytania i odpowiedzi - zgłaszanie do ZUS umów o dzieło, https://www.zus.pl/ baza-wiedzy/katalog-uslug/karty-uslug-inne (dostęp: 18 kwietnia 2021).

\section{Orzecznictwo}

Wyrok Naczelnego Sądu Administracyjnego z dnia 5 stycznia 2021 roku, II GSK 1522/18, LEX nr 3119192.

Wyrok Sądu Apelacyjnego w Białymstoku z dnia 18 czerwca 2013 roku, I ACa 232/13, LEX nr 1498861.

Wyrok Sądu Najwyższego z dnia 7 kwietnia 2011 roku, I PK 232/10, LEX nr 1165751.

Wyrok Sądu Najwyższego z dnia 6 września 2012 roku, II PK 35/12, LEX nr 1619647.

Wyrok Sądu Najwyższego z dnia 6 grudnia 2012 roku, I PK 128/12, LEX nr 1284749.

Wyrok Trybunału Konstytucyjnego z dnia 2 marca 1994 roku, W 9/93, Dz.U. 1994, nr 45, poz. 184.

Wyrok Trybunału Konstytucyjnego z dnia z 26 października 1999 roku, K 12/99, Dz.U. 1999, nr 91, poz. 1042.

Wyrok Trybunału Konstytucyjnego z dnia 20 listopada 2002 roku, K 41/02, MP 2002, nr 56, poz. 763.

Wyrok Trybunału Konstytucyjnego z dnia 20 czerwca 2005 roku, K 4/04, Dz.U. 2005, nr 124, poz. 1042.

Wyrok Trybunału Konstytucyjnego z dnia 12 grudnia 2005 roku, K 32/04, Dz.U. 2005, nr 250, poz. 2116. 
Wyrok Trybunału Konstytucyjnego z dnia 11 maja 2007 roku, K 2/07, Dz.U. 2007, nr 85, poz. 571.

Wyrok Trybunału Konstytucyjnego z dnia 17 czerwca 2008 roku, K 8/04, Dz.U. 2008, nr 110, poz. 707.

Wyrok Trybunału Konstytucyjnego z dnia 19 czerwca 2008 roku, P 23/07, Dz.U. 2008, nr 116, poz. 740 .

\section{Akty prawa krajowego}

Konstytucja Rzeczypospolitej Polskiej z dnia 2 kwietnia 1997 roku, Dz.U. 1997, nr 78, poz. 483 z dnia 16 lipca 1997 roku.

Rozporządzenie Ministra Rodziny i Polityki Społecznej z dnia 20 grudnia 2020 roku w sprawie określenia wzorów zgłoszeń do ubezpieczeń społecznych i ubezpieczenia zdrowotnego, imiennych raportów miesięcznych i imiennych raportów miesięcznych korygujących, zgłoszeń płatnika składek, deklaracji rozliczeniowych i deklaracji rozliczeniowych korygujących, zgłoszeń danych o pracy w szczególnych warunkach lub o szczególnych charakterze, raportów informacyjnych, oświadczeń o zamiarze przekazania raportów informacyjnych, informacji o zawartych umowach o dzieło oraz innych dokumentów, Dz.U. 2020, poz. 2366.

Rozporządzenie Prezesa Rady Ministrów z dnia 20 czerwca 2002 roku w sprawie „Zasad techniki prawodawczej", Dz.U. 2016, poz. 283 tekst jedn.

Ustawa z dnia 23 kwietnia 1964 roku - Kodeks cywilny, Dz.U. 2020, poz. 1740 tekst jedn.

Ustawa z 13 października 1998 roku o systemie ubezpieczeń społecznych (Dz.U. 2021, poz. 423 tekst jedn.

Ustawa z dnia 31 marca 2020 roku o zmianie ustawy o szczególnych rozwiązaniach związanych z zapobieganiem, przeciwdziałaniem i zwalczaniem COVID-19, innych chorób zakaźnych oraz wywołanych nimi sytuacji kryzysowych oraz niektórych innych ustaw, Dz.U. 2020, poz. 568. 